\title{
Globalization and Higher Education in Taiwan
}

\author{
Dian-Fu Chang1, Cheng-Ta Wu², \\ Gregory Ching, Chia-wei Tang and Lin Xiao ${ }^{1}$ \\ ${ }^{1}$ National Chi Nan University, \\ ${ }^{2}$ National Cheng Chi University, \\ Taiwan
}

\section{Introduction}

Within the last decade, Taiwan's higher education system has experienced transformation along the lines of decentralization and marketization (Mok, 2000). The pressure to compete internationally and to attain global recognition has become one of the major benchmarks in evaluating university performance (Mok, 2003; Song \& Tai, 2007). Together with rising concerns about the value of money, public accountability has already changed the way higher education is governed (Welch, 2004). Advanced nations, such as the UK (with its University Appropriations Committee) and the US (with its Higher Education Project Funds in the Department of Education), along with Japan and Germany, have all allocated funds to assist in the development of key universities.

In Taiwan, the government has realized that globalization has accelerated competition among universities around the world (Lo \& Weng, 2005; Lu, 2004; MOE, 2006). A series of large-scale projects were launched in order to catch up with the rest of the world's higher education systems amid the powerful trend of globalization (Song \& Tai, 2007). With the revision of the University Act in 1994, which prompted the restructuring of state owned higher education institutions (HEIs) into independent legal entities (Mok, 2006), thereby reducing the control of the Ministry of Education (MOE) over HEIs and making campus operations more flexible. In the following years, Taiwan's government, acknowledging that the state alone can never satisfy the pressing demand for higher education, decided to revise its education ordinances and create room for the expansion of private higher education (Mok, 2000; Mok \& James, 2005). This sparked a growth in the number of HEIs over the decades. Currently, the number of HEIs has increased dramatically from 7 in 1950 to 164 in 2008, among which are 100 universities, 49 colleges, and 15 junior colleges (MOE, 2008). This sudden increased in numbers of HEIs did not only inflame the competition among HEIs, but also hasten the internationalization of Taiwan's HEIs.

Among the major projects Taiwan's MOE organized the Plan to Develop First-class Universities and Top-level Research Centers is the project with largest competitive fund. The empirical part of this paper analyzes the outcome of this project, adopted by the Taiwan Ministry of Education, in creating world-class universities and research centers. The prospective performances of the funded universities were evaluated with official data from the Department of Higher Education in Taiwan. The following section shall discuss the definition of globalization and internationalization of Taiwan's higher education, which is 
then followed by the details of the Plan to Develop First-class Universities and Top-level Research Centers and lastly the empirical findings of the efficiency of the MOE's effort of producing world class universities.

\section{Globalization and internationalization}

The examination of globalization and internationalization as distinct processes is essential for serious scholarship addressing contemporary trends in higher education. Scholars agree that processes of globalization are unalterable while those representing internationalization remain fluid and changeable. Elkin, Devjee and Farnsworth (2008) note that, internationalization is not something that is either achieved or not achieved; rather it is an engagement with a range of dimensions (indicators). Internationalization represents university policy, initiatives, and practices that are adopted in response to the affects of globalization (Scott, 1998).

Internationalization at the national, sector, and institutional levels is defined as the process of integrating an international, intercultural, or global dimension, into the purpose, functions or delivery of higher education (Knight, 2004). Ellingboe (1998) added that internationalization is the ongoing process of integrating an international perspective into HEIs. It should encompass a multi-dimensional, inter-disciplinary, and future-oriented leadership vision, which involves the many stakeholders of the institution, in order to respond and adapt appropriately to the ever increasingly diverse and global environment. Hence, the many definitions and dimensions of internationalization have definitely given grounds to its complexity.

On the other hand, globalization is considered a multi-dimensional term (Levin, 1999). Commonly, globalization is defined as the closer integration of the countries and peoples of the world, brought about by the enormous reduction of costs of transportation and communication, and the breaking down of artificial barriers to the flows of goods, services, capital, knowledge, and people across borders (Stiglitz, 2002). It also refers to the process and consequences of instantaneous communication and technological advancement, which brought about the tremendous growth in the quantity of information and integration (Grunzweig \& Rinehart, 2002). While academic systems and institutions may make different accommodations to these trends, however neither one can ignore its impetus and implications. Globalization, as it applies to higher education, involves information technology and the use of a common language for scientific communication (Altbach, 2005). In effect, the rapidly changing world thus requires students to possess broad international knowledge and strong intercultural skills, in addition to the more traditional disciplinary knowledge gained from university education (Paige, 2005).

\section{Effects of globalization in Taiwan}

Education system in Taiwan, similar to other education systems in East Asia, has undergone an enormous transformation over the last two decades. Education has become interconnected with trends of globalization and internationalization, development of information communications technology, and a set of political, sociological, economic, and management changes. These changes together produce multifaceted influences on Taiwanese education. In particular, the ideology of globalization and localization acts as one of the driving policy agenda in Taiwan. The notion of globalization encompasses a plethora 
of meanings. According to Mok and Lee (2000: 362), globalization is "the processes that are not only confined to an ever growing interconnectedness and interdependency among different countries in the economic sphere but also to tighter interactions and interconnections in social, political, and cultural realms". Governments in Taiwan have endeavored to follow the trend of globalization, especially in education.

In the efforts of Taiwanese educational globalization, English instruction was very much emphasized throughout primary and secondary education. In earlier history of education in Taiwan, English was only instructed in secondary schools as one of the compulsory classes. However, as to follow the trend of globalization and to connect with the world internationally, Taiwanese government started to push second language instruction into primary schools, targeting fifth and sixth graders in the elementary level in 2001, in order to cultivate their youth to become internationally competitive. In 2008, Taipei County's Ministry of Education even launched a program that adds three extra courses to the current elementary school curriculum that focuses on English learning, which was met with harsh criticism from teachers, claiming that the current Taiwanese curriculum for elementary school students already takes up too much of children's free time (Lu, 2010).

In the past several decades, the development of communicational technology made it possible to view Taiwanese television programs in many parts of the world; transportation technology has also dramatically changed the face of Taiwanese education. Now, foreign students, international students, sister schools, and exchange programs are quite common in Taiwanese higher education. According to statistics, in 2007 there were at least 86 Taiwanese universities, colleges, and vocational schools that had established a sister school relationship with around 173 Chinese schools (Yu, 2007). It is also not uncommon for a post secondary school to have a large number of sister schools from all over the world; for example, the National Chengchi University in Taiwan has around 234 sister schools from 35 countries as of November, 2009 (National Chengchi University, Office of International Cooperation). Chengchi University also has a renowned IMBA (International Master of Business Administration) program which offers all of its courses completely in English, with students from over 30 countries in 5 continents.

The effect of globalization on Taiwanese education can be clearly observed not only in Taiwan, but in other parts of the world as well, as globalization is not just a one-way process. As Taiwan joins WTO (World Trade Organization) and signs the ECFA (Economic Cooperation Framework Agreement) with China, the opening of trade between China and Taiwan has created a number of Taiwanese schools in China that caters to the children of Taiwanese businessmen working in Chinese companies, such as Taiwan Businessmen's Dongguan School, Shanghai Taiwanese Children School, and HuaDong Taiwan Businessmen's School. In 2010, Taiwan also plans to start recognizing diplomas from 41 specified Chinese universities and colleges, and accept Chinese students into the Taiwanese post secondary education system with strict regulation, which has generated mixed responses from the public due to political reasons and a fear of competition in the job market.

Other than China, there are also Taiwanese schools in Vietnam's Ho Chi Ming City, Indonesia's Surabaya City and Jakarta City, and Malaysia's Seberang Perai and Kuala Lumpur. While Taiwan is opening up to the world, the world is also learning about the culture of Taiwan. Currently, the Taiwanese government is planning to establish Taiwanese Institutes in other parts of the world, starting with the United States of America's Los Angeles and Houston (Tsai, 2010). The goal of such institutes is to promote Taiwanese 
culture and language, very much like China's Confucius Institutes which already has over 282 institutes in 88 countries as of November 2009. Another the key unique issues in Taiwanese education are the minority population, such as aboriginal children and children of foreign spouses. There are around five hundred thousand aboriginal people in Taiwan; in the school year of 2008, their rate of enrollment at the elementary school level is $99.22 \%$, the rate at the level of high school and below is $85.88 \%$, and the rate of enrollment at post secondary education is $41.46 \%$ (compared to $84.30 \%$ in the general population). A 2009 poll of the aboriginal population over 15 years of age showed that $85.88 \%$ of all aboriginal people have a level of education at or below high school and vocational schools. The reason that aboriginal students have a significantly lower enrollment rate is often linked with family or economic problems, along with troubles fitting in at school.

Another significant measure under the influence of globalization is the nine-year spiral curriculum reform in secondary education taken place in 2001. The objective of this curriculum reform program is considered the backbone of the major educational reform during the last decade. Its major goals are to promote cultural learning and international understanding as well as other demanding abilities for the 21st century. In order to achieve educational globalization, related issues and ideas were implemented within secondary curriculum in subjects such as civil and social studies. The Taiwanese Ministry of Education (MOE) also stressed globalization in higher education.

Taiwan follows the world trend of higher education globalization, redirecting the aim of education toward a more market-oriented one. Lessening government control and integrating social demand with market forces, Taiwanese education in the 1990s has been influenced by globalization to a great extent. Similarly, beginning in 2003, MOE started to promote a "World Class Research University" project, proposing to upgrade at least one of the universities in Taiwan to be ranked among the top 100 leading international institutions of higher education within the next 10 years. Universities are required to establish a system of evaluation using methods such as the SCI, SSCI, and the EI, or to be in accordance with the standards that meet international recognition for awards, achievements, and contributions within their field of expertise. In 2005, MOE granted NT\$50 billion (equals US $\$ 1.56$ billion) to 12 universities for five years to empower their research capacity in order to reach the world class level. This paper shall ultimately analyze the efficiency of having embark in such efforts to become recognized as the so-called World Class Universities.

\section{Plan to develop first-class universities and top-level research centers}

In virtue of the already limited resources that were further diminished by the growth in higher education and its attendant pursuit of excellence, MOE was aware of that instead of assisting all HEIs; they needed to invest extra funding in selected promising institutions. Based on this concern, Plan to Develop First-class Universities and Top-level Research Centers was put forth according to suggestions made in the Higher Education Macroscopic Planning Report prepared by the Higher Education Macroscopic Planning Committee, which proposed strategies that would raise the level of competitiveness among institutions of higher education. The plan was comprised of two sub-plans: Plan to Develop First-class Universities and Plan to Develop Top-level Research Centers. The purpose of these plans was to assist universities through competitive funding and thus improve their worldwide academic competitiveness. The main objectives of this project can be summarized as follows (MOE, 2006): 
1. In ten years, at least one university will become one of the world's top one hundred universities. In fifteen to twenty years, that university will become one of the world's top fifty universities, with several research centers in that university having the potential of becoming some of the world's Top-level research centers.

2. At least ten outstanding fields, departments, or research centers will become Asia's First-class areas within five years. In ten years, these will have the potential of becoming among the top fifty in their respective fields.

3. The R\&D quality of universities will be raised, as will their influence on and visibility in international academic circles.

4. Distinguished foreign teaching and research individuals will be recruited to train students in cutting-edge industries.

5. Substantive exchange and cooperation will be established among transnational academic organizations.

\section{Project application and review procedure}

This project targeted the promotion of excellence in promising HEIs. The selection of recipients required HEIs to submit a written preliminary project proposal for review. After a list of passing HEIs was posted, each school briefed the review committee. If several schools were going to consolidate, they had to submit a joint consolidation proposal. The items required in each project proposal included current status and self-assessment of the school's competitive edge, year-by-year assessment indicators, strategies to achieve objectives, and financial planning with year-by-year funding requirements.

Proposal reviews were held thrice, in 2005, 2007, and the most recent 2010. The review committee consisted of highly esteemed academics and experts, from both Taiwan and abroad, who were responsible for identifying the HEIs that had the potential to become firstclass in their respective fields. The review standards and criteria for Plan to Develop Firstclass Universities included the management and organizational operating system of the school as well as the school infrastructure, staffing quality, and research performance. The review standards and criteria for Plan to Develop Top-level Research Centers included the quality of teaching and research personnel; steps taken to recruit distinguished individuals; the rise in teaching performance, creative mechanisms, and methods of academic research; the methods used to cooperate with domestic and foreign schools, research institutions, and results; the school's overall support resources; and qualitative indicators designated by the review committee (MOE, 2006).

In the first round of review during 2005, twenty-nine universities submitted proposals for funding under the program, with twelve selected (two universities as the recipients of Plan to Develop First-class Universities and ten key universities or research centers were also selected for Plan to Develop Top-level Research Centers). These twelve universities are during that time have been thought of as (but not universally shared) the twelve best universities in Taiwan. Among the twenty-nine universities, seven submitted applications for funding as world class universities, with twenty-two universities putting forward research centre proposals16.

During the second round of review in 2007, only eleven universities remained. While the latest results of the 2010 review resulted in only ten universities (all national universities) are funded by the Taiwanese MOE. The main purpose of this study was to evaluate the effects and outcomes of the project called Plan to Develop First-class Universities and Top-level 
Research Centers, which has brought in selected universities since its implementation in 2005. Descriptive statistics and the data envelopment analysis (DEA) method were adopted during data analysis to weigh the relative performance of twelve recipient universities in Taiwan between and to 2007. (Please see table 1 for funding details)

\begin{tabular}{ccccccc}
\hline \multicolumn{7}{c}{ Year-by-year budgets for various sub-plans of the Plan (in NT\$ $100 \mathrm{M}^{1}$ ) } \\
\hline Phase 1 & 2005 & 2006 & 2007 & 2008 & 2009 & Total \\
Total Budget & 100 & 100 & 100 & 100 & 100 & 500 \\
First-class Universities & $35-60$ & $35-60$ & $35-60$ & $35-60$ & $35-60$ & $175-300$ \\
Top-level Research Centers & $40-65$ & $40-65$ & $40-65$ & $40-65$ & $40-65$ & $200-325$ \\
\hline Phase 2 & 2010 & 2011 & 2012 & 2013 & 2014 & Total \\
Total Budget & 100 & 100 & 100 & 100 & 100 & 500 \\
First-class Universities & $35-60$ & $35-60$ & $35-60$ & $35-60$ & $35-60$ & $175-300$ \\
Top-level Research Centers & $40-65$ & $40-65$ & $40-65$ & $40-65$ & $40-65$ & $200-325$ \\
\hline
\end{tabular}

Source: Plan to Develop First-class Universities and Top-level Research Centers, MoE, 2006. Retrieved July 3, 2008, from http:/ / english.MoE.gov.tw/ct.asp?xItem=7131\&ctNode=505\&mp=1

Note: 1 Exchange rate: US $\$ 1=30$ NT $\$$

Table 1. Year-by-year budgets for Plan to Develop First-class Universities

The analysis asked and answered the following research questions:

1. Did the project promote the global competitiveness of selected recipients in terms of research and development activities and internationalization?

2. Among the twelve recipients, which universities are comparatively efficient and inefficient?

\section{An overview of DEA method}

DEA has developed considerably since its inception by Farrell in 1957. It is a powerful method widely used in the evaluation of the performance of DMUs. DEA evaluates efficiency, i.e. the relationship between inputs and outputs. It thereby determines overall efficiency, which consists of both purely technical efficiency and allocative efficiency. The classical efficiency measure of Farrell (1957) was generalized by Charnes, Cooper, and Rhodes (1978) as a response to the need to evaluate the efficiency of not-for-profit organizations. They introduced the ratio definition of efficiency, which generalizes the single-output to single-input ratio definition used by Farrell (1957) to multiple outputs and inputs. In this model, DMU efficiency measurement is defined as each organization's mathematical position as it relates to the frontier of best performance, which is established by the ratio of weighted sum of outputs to weighted sum of inputs.

$$
\max \frac{\text { sum of weighted outputs }}{\text { sum of weighted inputs }}
$$

Each DMU uses $m$ inputs and $s$ outputs. DMUj $(j=1, \ldots, n)$ takes the quantity $x_{i j}$ of input $\mathrm{i}$ and the quantity $\mathrm{y}_{r j}$ of output $r$. This means that $x_{i} \geq 0$ and $\mathrm{y}_{\mathrm{rj}} \geq 0$, and each DMU has at least one positive input and output value. Let $u_{r}$ and $v_{i}$ be the weight of output $r$ and of input $i$, respectively, $\mathrm{y} r_{k}$ and $x i_{k}$ being the observed values of the DMU $k$ under evaluation. The weights are fixed at the beginning and are calculated within the analysis. The mathematical model for a DMUk, is defined by: 
$\operatorname{Max} E_{k}=\frac{\sum_{r=1}^{s} u_{r} Y_{r k}}{\sum_{i=1}^{m} v_{i} X_{i k}}$

$$
\begin{gathered}
\text { Subject to } \frac{\sum_{r=1}^{s} u_{r} Y_{r j}}{\sum_{i=1}^{m} v_{i} X_{i j}} \leq 1 \quad j=1,2, \ldots, n \\
u_{r}, v_{i} \geq \varepsilon \quad r=1,2, \ldots, s \quad i=1,2, \ldots, m
\end{gathered}
$$

This model focuses on proportional improvement and reduction potentials. $\theta$ is the proportional decrease in inputs possible for the k-th DMU. $\varepsilon$ is a very small positive constant. An efficiency score of $\theta$ (the reduction factor of the inputs) will be assigned to its respective DMU. For $\theta<1$, the DMU is inefficient (Leitner, Schaffhauser-Linzatti, Stowasser, \& Wagner, 2005).

\section{Empirical findings}

To answer the research questions of this study, descriptive statistics and the DEA method were adopted in data analysis. For descriptive statistics, survey data from the Higher Education Department and the MOE were adopted, which projected an overview of the outcome of this project after two years' implementation. In order to gain further insight into the efficiency of funding recipients, the DEA method was adopted. One input and six outputs have been incorporated into the Charnes, Cooper, and Rhodes (CCR) model. The sole input of this project was monetary funding. According to MOE (2006), in 2005, NT\$100 million was allocated for twelve recipients. Funding received by schools in 2005 (NT\$ 100 million) is shown in Table 2.

\begin{tabular}{ccc}
\hline Code & School & Amount \\
\hline 1 & National Taiwan University & 30 \\
2 & National Cheng Kung University & 17 \\
3 & National Tsing Hua University & 10 \\
4 & National Chiao Tung University & 8 \\
5 & National Central University & 6 \\
6 & National Sun Yat-Sen University & 6 \\
7 & National Yang Ming University & 6 \\
8 & National Chung Hsing University & 6 \\
9 & National Taiwan University of Science and Technology & 6 \\
10 & National Chengchi University & 3 \\
11 & Chang Gung University & 3 \\
12 & Yuan Ze University & 3 \\
\hline
\end{tabular}

Source: Plan to Develop First-class Universities and Top-level Research Centers, MoE, 2006. Retrieved July 3, 2008, from http:/ /english.MoE.gov.tw/ct.asp?xItem=7131\&ctNode=505\&mp=1

Note: ${ }^{1}$ NT\$100 million approximately equal to US\$ 3 million (based on US\$1 $=$ NT\$30)

Table 2. Funding received by schools in 2005 (NT\$100 million) ${ }^{1}$ 
According to the MOE (2006), the goal of the project was to enhance the performance of selected universities in terms of research and development (R\&D) quality and internationalization. In consideration of this objective and of the availability of related data, the outputs included in this study's DEA model were: number of degree-seeking international students; number of international exchange students; number of international collaborations; number of visiting international scholars; number of articles published in international journals that are indexed in the Science Citation Index (SCI), Social Science Citation Index (SSCI), and Arts and Humanities Citation Index (A\&HCI) databases; and national scientific and educational collaboration expenditures in the form of new Taiwan dollars.

Results as shown in figures 1 through 6 show the growth rates of selected output measures in 2006. In general, it is suggested that substantial progress was made within the year that the project launched. Negative growth rates only appeared in the two right-hand columns, which show the number of articles published in international journals and the national scientific and educational collaboration expenditures (see Figure 6). As for the former, the rate of decline was rather slight. One possible reason that some of the universities gained fewer opportunities for national scientific and educational collaboration expenditures than others did was that the total number of such opportunities was usually constant. If one university acquired money through cooperation, it created a loss for others. In sum, although it was only the first year of the MOE's project, twelve universities experienced immediate and apparent improvement in many aspects of internationalization and R\&D development.

Both Chang Gung and Yuan Ze Universities experienced an increase in the growth rate of degree-seeking international students (see Figure 1), while Yang Ming University experienced an increase in the growth rate of international exchange students (see Figure 2). As was discovered after further analysis of these schools' internationalization strategies, some of their policies included scholarships for foreign students, dual bachelor's and master's degree programs, and foreign language courses.

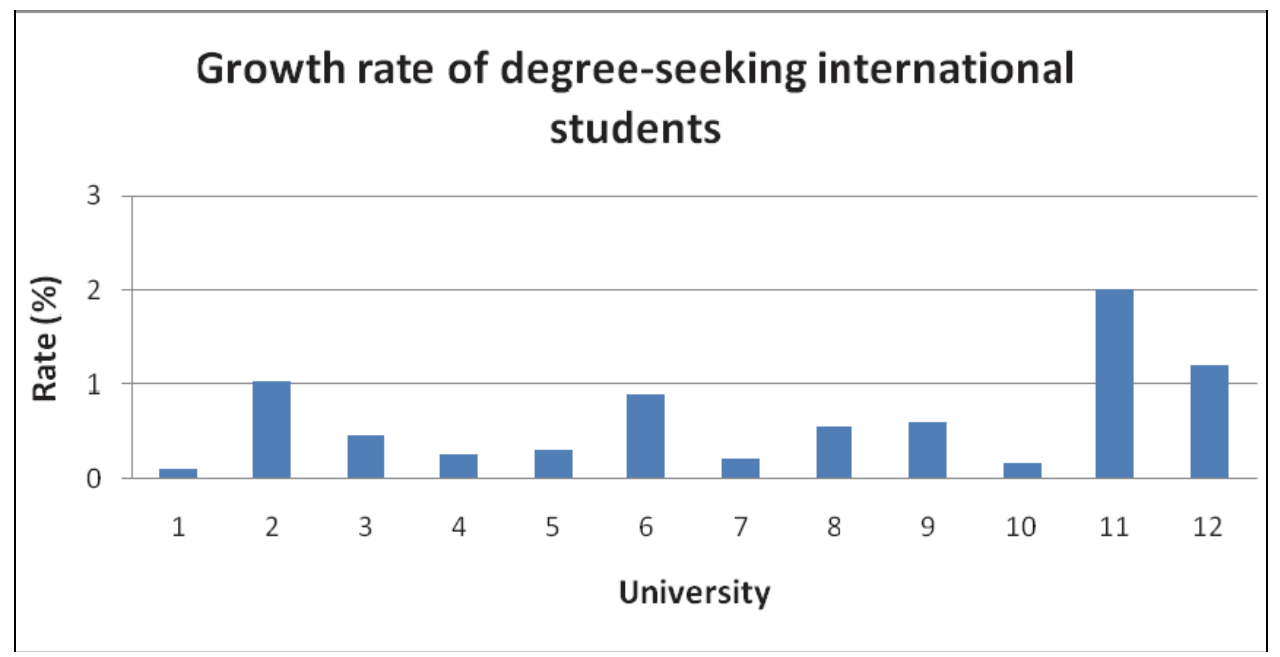

Fig. 1. 


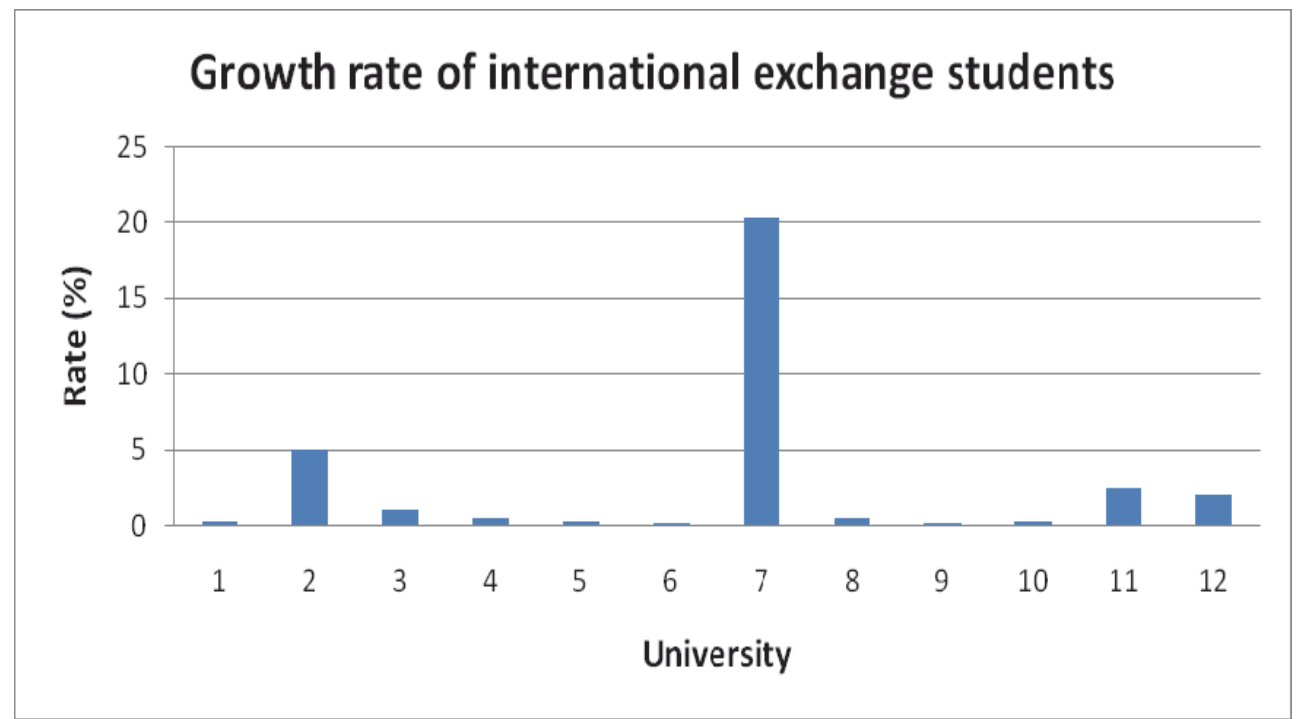

Fig. 2.

As for international collaboration, most of the universities experienced large growth rates during the one-year period (see Figure 3). Common strategies included establishing international sister schools, organizing international research teams, hosting international academic conferences, and making flexible degree programs available. Chung Hsing University showed particularly outstanding performance in the number of visiting international scholars (see Figure 4) and adopted policies such as flexible compensation in order to attract international and world-class scholars and to create scholarship opportunities for foreign faculty.

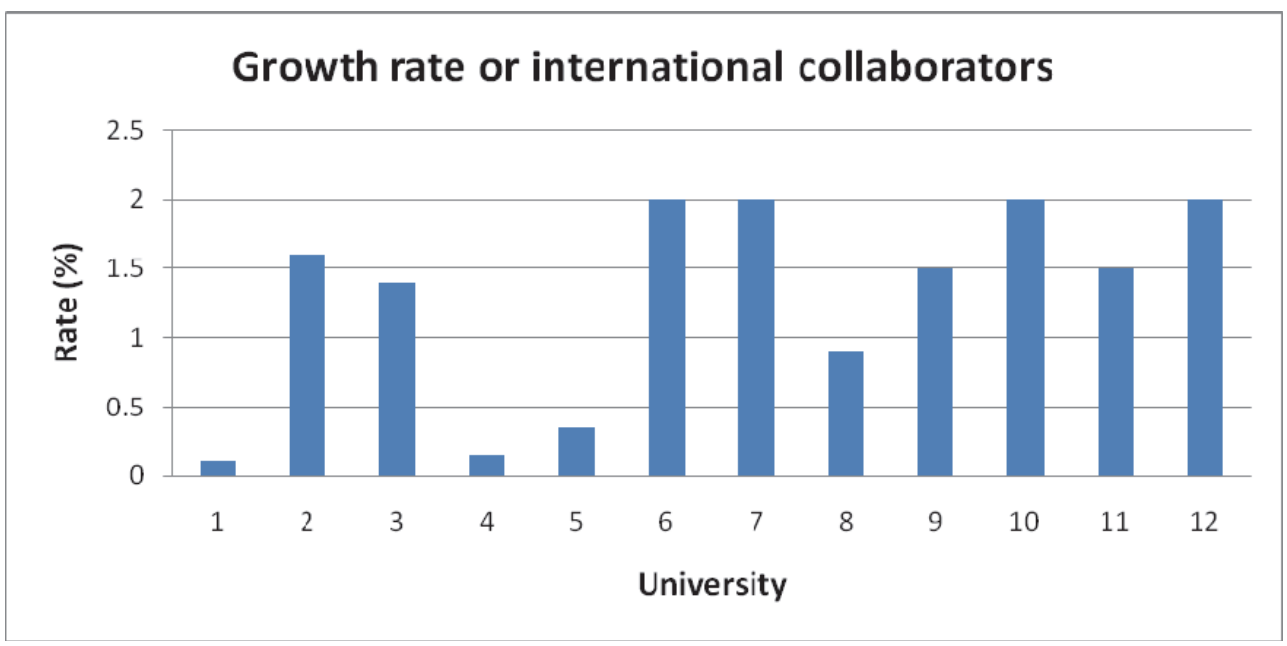

Fig. 3. 


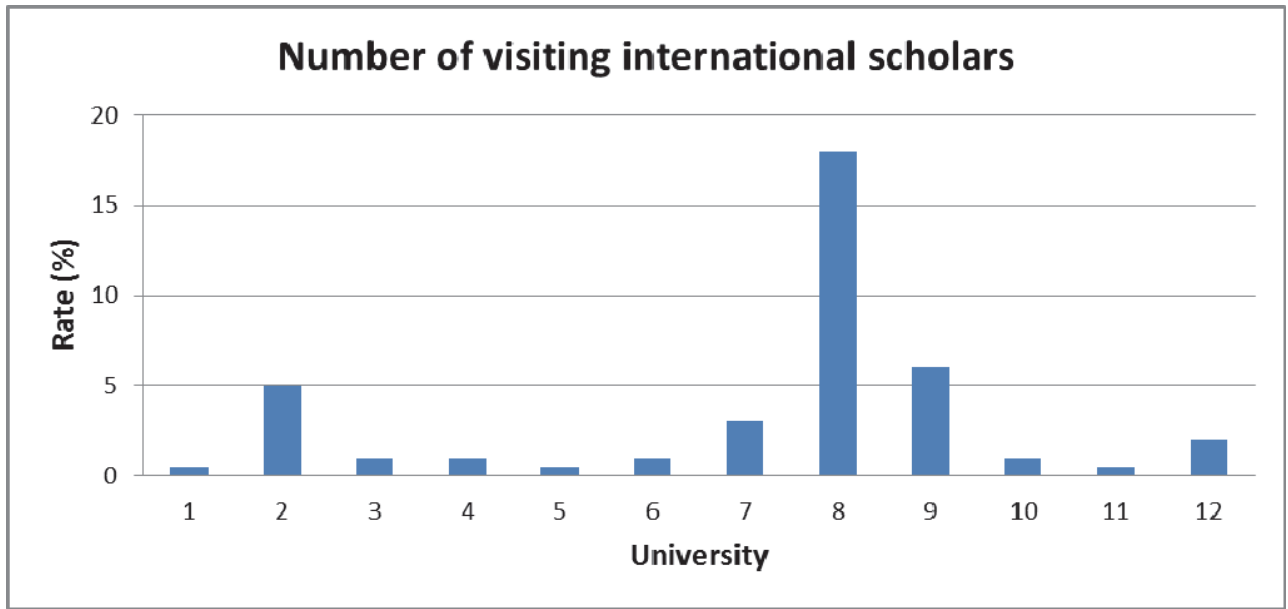

Fig. 4.

An overall similarity among the above-mentioned schools was the existence of an international education exchange center that handles all of the university's internationalization tasks. This setup not only increases the visibility of the university in the international arena, but also maintains good relations with foreign institutions and students. It helps better facilitate the activities of inbound foreign students and outbound local students. It also helps coordinate exchange opportunities and provides an array of services that prepare students for whatever challenges they may face when coming to Taiwan to study or when leaving Taiwan to study abroad.

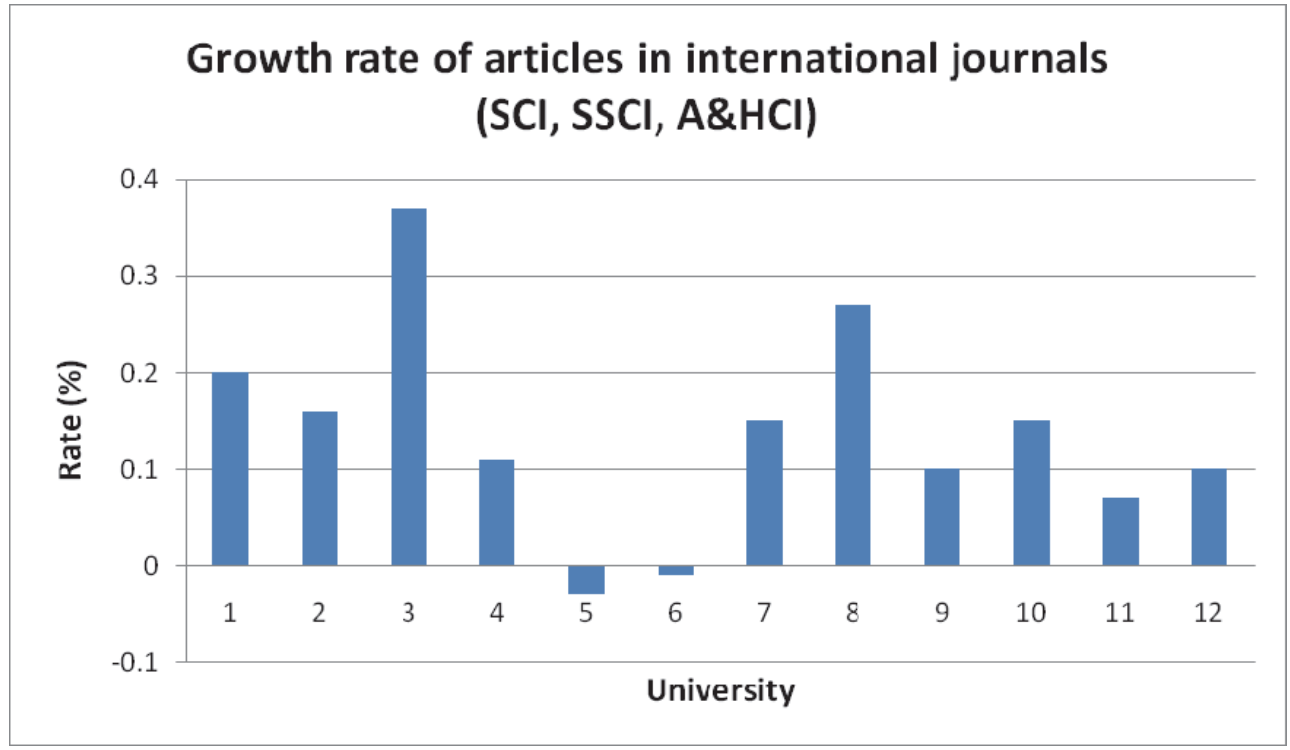

Fig. 5. 
With regard to publications in foreign international journals, most schools showed an increased growth rate; Tsing Hua, Chung Hsing, and National Taiwan Universities showed the highest increases (see Figure 5). These schools adopted policies such as funding assistance for research projects and additional monetary incentives for each publication in an international journal, especially those indexed in SCI/SSCI/A\&HCI. These have sparked an increase in the number of Taiwanese scholars in the international academe.

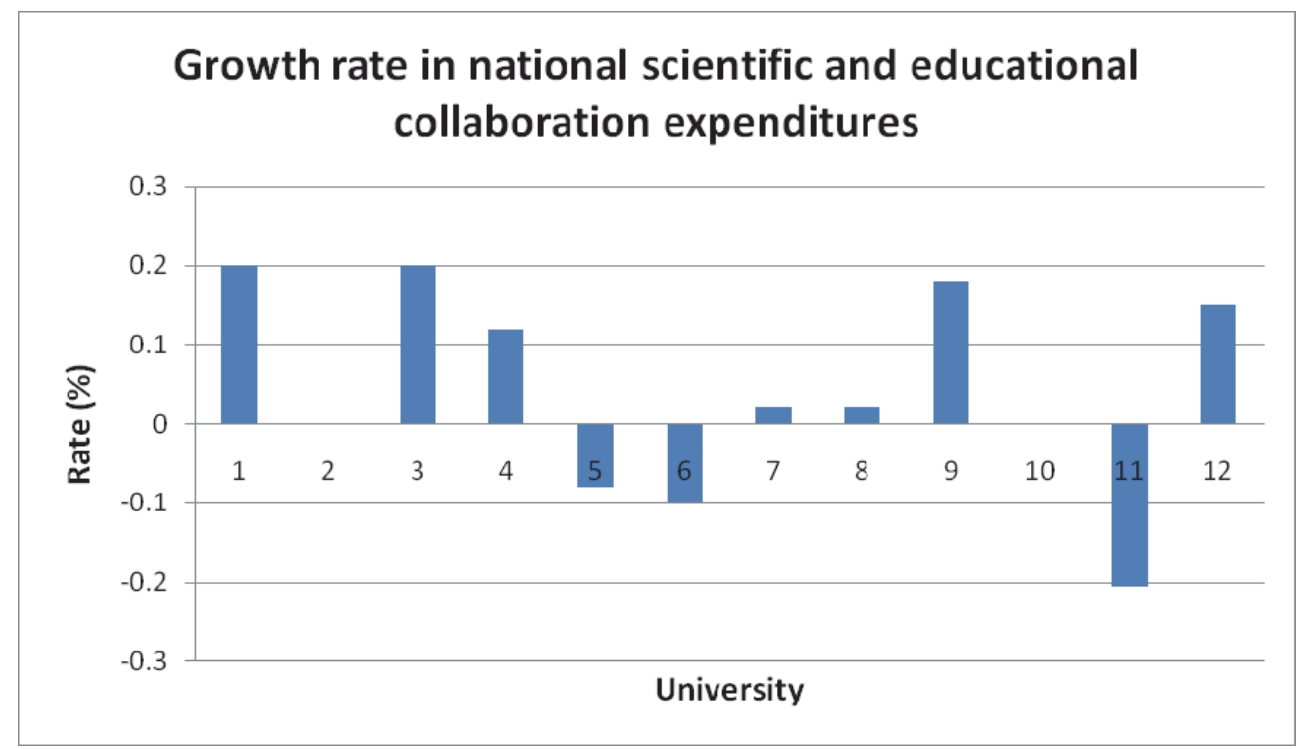

Fig. 6.

\section{Conclusions}

The development of first-class universities and top-level research centers requires a large investment of time and money, and yearly performance evaluation is crucial in order for the recipients to move in the right direction and to be accountable for their actions (MOE, 2006). This section includes a glimpse at the overall performance of the twelve recipients one year after this project launched. The end of this section will address information that compares efficient Decision Making Units (DMUs) with inefficient DMUs.

The empirical results of the DEA analysis provided valuable diagnostic information. First, based on the six output measures and the single input (total amount of funding received), we calculated the efficiency score for twelve universities with reference to other efficient DMUs. Moreover, the surplus analysis provided suggestions for managerial auditing. As Table 3 indicates, five universities were relatively efficient; these are marked with an efficiency score of 100, which implies that their resource utilization was comparatively efficient. That score represents the percent of outputs one DMU produced in comparison with efficient DMUs when the same efficiency level was predicted. Taiwan University is a good example: its efficiency score was 71.44 , which shows that it attained $71.44 \%$ efficiency as compared with the efficient DMUs. That is to say, Taiwan University only produced $71.44 \%$ of the output that efficient universities produced with the same level of input. 


\begin{tabular}{|l|c|c|c|}
\hline \multicolumn{1}{|c|}{ DMU } & Efficiency Score & Reference Frequency & Rank \\
\hline 1. National Taiwan University & 71.44 & 0 & 9 \\
\hline 2. National Cheng Kung University & 67.78 & 0 & 10 \\
\hline 3. National Tsing Hua University & 81.33 & 3 & 8 \\
\hline 4. National Chiao Tung University & 88.35 & 3 & 7 \\
\hline 5. National Central University & 100 & 7 & 1 \\
\hline 6. National Sun Yat-Sen University & 65.52 & 0 & 11 \\
\hline 7. National Yang Ming University & 56.41 & 0 & 12 \\
\hline 8. National Chung Hsing University & 100 & 6 & 4 \\
\hline 9. Nat. Taiwan Univ. of Science \& Tech. & 92.95 & 0 & 6 \\
\hline 10. National Chengchi University & 100 & 7 & 1 \\
\hline 11. Chang Gung University & 100 & 7 & 1 \\
\hline 12. Yuan Ze University & 100 & 2 & 5 \\
\hline
\end{tabular}

Table 3. Relative efficiency of DMUs

With the recent rise in globalization and the increasing trend toward placing importance on university rankings, governments worldwide have started to focus on developing first-class universities. This study focused on Taiwan's experience with the project Plan to Develop First-class Universities and Top-level Research Centers. DEA was utilized in order to analyze the comparative performance of the twelve universities involved in the project. Data were gathered from before and after project implementation. The results indicate that even though this project had only been implemented for a single year, all the universities involved showed tremendous increase in the growth rates of their R\&D performance and their internationalization progress. Although some universities, such as National Chengchi University and Chang Gung University, received much less funding from the MOE than others did, they managed to outperform other universities that received much more. Similarly, two of the other efficient DMUs (Yuan Ze University and Chung Hsing University) received only NT\$600 million, while most DMUs with lower rankings received more funding from the MOE. This suggests the possibility that, due to limited recourses, universities tend to use their funding carefully and thus rapidly reach their prospective development goal. On the other hand, more input did not ensure better output, which might be cause by deterioration due to the overinvestment or misuse of budgets. Further longitudinal studies are necessary in order to attain a broader view of the whole project. An additional analysis of the factors behind the strategies used by those universities that performed best are also encouraged.

\section{References}

Altbach, P. G. (2005). Globalization and the university: Myths and realities in an unequal world. In The NEA 2005 Almanac of Higher Education (pp. 63-74). Washington, DC: National Education Association.

Charnes, A., Cooper, W. W., \& Rhodes, E. (1978). Measuring the efficiency of decision making units. European Journal of Operational Research, 2, 429-444.

Elkin, G., Farnsworth, J., \& Templer, A. (2008). Strategy and the internationalisation of universities. International Journal of Educational Management, 22(3), 239-250. 
Ellingboe, B. J. (1998). Divisional strategies to internationalize a campus portrait: Results, resistance, and recommendations from a case study at a US university. In J. A. Mestenhauser \& B. J. Ellingboe (Eds.), Reforming the higher education curriculum: Internationalizing the campus (pp. 198-228). Washington, DC: American Council on Education.

Farrell, M. J. (1957). The measurement of productive efficiency. Journal of the Royal Statistical Society, 120, 253-281.

Grunzweig, W., \& Rinehart, N. (Eds.). (2002). Rocking in red square: Critical approaches to international education in the age of cyberculture. Berlin: Lit Verlag.

Knight, J. (2004). Internationalization remodeled: Definition, approaches, and rationales. Journal of Studies in International Education, 8(1), 5-31.

Leitner, K.-H., Schaffhauser-Linzatti, M., Stowasser, R., \& Wagner, K. (2005). Data envelopment analysis as method for evaluating intellectual capital. Journal of Intellectual Capital, 6(4), 528-543.

Levin, J. S. (1999). Missions and structures: Bringing clarity to perceptions about globalization and higher education in Canada. Higher Education, 37, 377-399.

Lo, Y. W., \& Weng, F. Y. (2005). Taiwan's responses to globalization: Internationalization of higher education. In K. H. Mok \& R. James (Eds.), Globalization and higher education in East Asia. Singapore: Marshall Cavendish Academic.

Lu, M. L. (2004). The blueprint and competitiveness of Taiwan's higher education. Paper presented at the Cross Strait Seminar on Review and Prospect of the Policy of University Excellence.

MOE. (2006). Plan to develop first-class universities and top-level research centers. Retrieved July 3, 2008, from http:/ / english.moe.gov.tw/ct.asp?xItem=7131\&ctNode=505\&mp=1

MOE. (2008). 2008 Educational statistical indicators. Retrieved May 25, 2008, from http:/ / english.moe.gov.tw/lp.asp?ctNode=816\&CtUnit=507\&BaseDSD=7\&mp=1

Mok, K. H. (2000). Reflecting globalization effects on local policy: Higher education reform in Taiwan. Journal of Education Policy, 15(6), 637-660.

Mok, K. H. (2003). Similar trends, diverse agendas: Higher education reforms in East Asia. Globalisation, Societies and Education, 1(2), 201-221.

Mok, K. H. (2006, January 13-14). Questing for internationalization of universities in East Asia: Critical reflections. Paper presented at the International symposium, Osaka University, Japan.

Mok, K. H., \& James, R. (Eds.). (2005). Globalization and higher education in East Asia. Singapore: Marshall Cavendish Academic.

Paige, R. M. (2005). Internationalization of Higher Education: Performance Assessment and Indicators. Nagoya Journal of Higher Education, 5, 99-122.

Scott, P. (1998). Massification, internationalization and globalization. In P. Scott (Ed.), The globalization of higher education. Buckingham: SRHE and Open University Press.

Song, M.-M., \& Tai, H.-H. (2007). Taiwan's responses to globalisation: Internationalisation and questing for world class. Asia Pacific Journal of Education, 27(3), 323-340.

Stiglitz, J. E. (2002). Globalization and its discontents. New York: W. W. Norton \& company. 
Welch, A. (2004). Accountability or accountability? Governance and university evaluation systems in an era of performativity. COE Publication Series, 11, 117-138. 


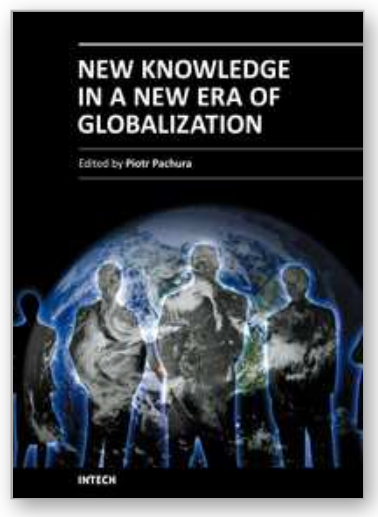

\author{
New Knowledge in a New Era of Globalization \\ Edited by Prof. Piotr Pachura
}

ISBN 978-953-307-501-3

Hard cover, 354 pages

Publisher InTech

Published online 01, August, 2011

Published in print edition August, 2011

To better understand the contemporary world, the world of innovation and technology, science should try to synthesize and assimilate social science in the development of our civilization. Does the new era require new knowledge? Does the age of globalization demand new education, new human attitudes? This books tries to clarify these questions. The book New Knowledge in a New Era of Globalization consists of 16 chapters divided into three sections: Globalization and Education; Globalization and Human Being; Globalization and Space. The Authors of respective chapters represent a great diversity of disciplines and methodological approaches as well as a variety of academic culture. This book is a valuable contribution and it will certainly be appreciated by a global community of scholars.

\title{
How to reference
}

In order to correctly reference this scholarly work, feel free to copy and paste the following:

Dian-Fu Chang, Cheng-Ta Wu, Gregory Ching, Chia-wei Tang and Lin Xiao (2011). Globalization and Higher Education in Taiwan, New Knowledge in a New Era of Globalization, Prof. Piotr Pachura (Ed.), ISBN: 978-953307-501-3, InTech, Available from: http://www.intechopen.com/books/new-knowledge-in-a-new-era-ofglobalization/globalization-and-higher-education-in-taiwan

\section{INTECH}

open science | open minds

\author{
InTech Europe \\ University Campus STeP Ri \\ Slavka Krautzeka 83/A \\ 51000 Rijeka, Croatia \\ Phone: +385 (51) 770447 \\ Fax: +385 (51) 686166 \\ www.intechopen.com
}

\author{
InTech China \\ Unit 405, Office Block, Hotel Equatorial Shanghai \\ No.65, Yan An Road (West), Shanghai, 200040, China \\ 中国上海市延安西路65号上海国际贵都大饭店办公楼405单元 \\ Phone: +86-21-62489820 \\ Fax: +86-21-62489821
}


(C) 2011 The Author(s). Licensee IntechOpen. This chapter is distributed under the terms of the Creative Commons Attribution-NonCommercialShareAlike-3.0 License, which permits use, distribution and reproduction for non-commercial purposes, provided the original is properly cited and derivative works building on this content are distributed under the same license. 